\title{
Mampukah Good Corporate Governance dan Risiko Kredit Sebagai Prediktor Financial Distress?
}

\author{
Elysa Lisitiana Putri ${ }^{1}$, Sugeng Haryanto ${ }^{2}$, Riril Mardiana Firdaus ${ }^{1}$
}

${ }^{1}$ Program Studi Manajemen, Fakultas Ekonomika dan Bisnis, Universitas Kanjuruhan Malang Jl. S. Supriyadi No. 48, Malang, 65148, Indonesia 2Program D3 Keuangan dan Perbankan Universitas Merdeka Malang J1. Terusan Raya Dieng No. 57, Malang, 65145, Indonesia

\section{Info Artikel}

Sejarah Artikel:

Diterima: 1 Juni 2018

Disetujui: 27 Juni 2018

Tersedia daring: Juli 2018

Keywords:

Bankruptcy; CAR; credit risk; financial distress; GCG; profitability.

ISSN (print) : 2598-7763 ISSN (online): 2598-7771

$\triangle$ Corresponding Author:

Elysa Listiana Putri:

Tel. /Fax. 085258746088

E-mail:elysaunikama@gmail.com

\section{Abtract}

This study aims to predict financial distress at Bank foreign exchange (BUSN) by using GCG analysis, credit risk, profitability, capital adequacy ratio and bank size. GCG, credit risk, and profitability. The population in this research is 35 BUSN of foreign exchange registered in Bank Indonesia. Sampling technique used purposive sampling. The sample size is 17 banks. Data analysis technique using linear regression. This research performs 4 regression test that is in BUSN of foreign exchange for all condition, financial distress condition, gray area condition, and condition of non financial distres. The results of this study indicate that GCG and credit risk have no effect on fianansial pressure for all conditions, financial distress condition, gray area condition, and non-financial distress condition. Profitability affects financial difficulties for all conditions, gray area conditions and non-financial distress conditions. CAR affects financial difficulties for all conditions, gray area conditions and non-financial pressure conditions. Profitability and CAR have no effect on financial difficulties for gray area conditions. The size of the bank affects financial difficulties in all conditions and grays, whereas in the financial distress position the size of the bank does not affect financial distress.

Citation: Putri, E.L., Haryanto, S., dan Firdaus, R.M. (2018). Mampukah Good Corporate Governance dan Risiko Kredit Sebagai Prediktor Financial Distress. Accounting and Financial Review, 1 (1)

\section{Abstraks}

Penelitian ini bertujuan untuk memprediksi financial distress pada BUSN Devisa dengan menggunakan analisis GCG, risiko kredit, profitabilitas, capital adequacy ratio dan ukuran bank. GCG, risiko kredit, dan profitabilitas. Populasi dalam penelitian ini adalah 35 BUSN devisa yang terdaftar di Bank Indonesia. Setelah melewati tahap purposive sampling terdapat 17 sampel bank. Teknik analisis data digunakan regresi linear bergamnda. Penelitian ini melakukan 4 uji regresi yaitu pada BUSN devisa untuk semua kondisi, kondisi financial distress, kondisi grey area, dan kondisi non financial distres. Hasil penelitian ini menunjukkan bahwa GCG dan risiko kredit tidak berpengaruh terhadap fianansial distress untuk semua kondisi, kondisi financial distress, kondisi grey area, dan kondisi non financial distress. Profitabilitas berpengaruh terhadap financial distress untuk semua kondisi, kondisi grey area dan kondisi non financial distress. CAR berpengaruh terhadap financial distress untuk semua kondisi, kondisi grey area dan kondisi non financial distress. Profitabilitas dan CAR tidak berpengaruh terhadap financial distress untuk kondisi grey area. Ukuran bank berpengaruh terhadap financial distress pada semua kondisi dan grey are, sedangkan pada posisi financial distress ukuran bank tidak berpengaruh terhadap financial distress.

JEL Classification: G32, G34 


\section{PENDAHULUAN}

Industri perbankan memegang peran penting bagi perekonomian nasional. Bank merupakan motor penggerak ekonomi. Perbankan menempati posisi yang strategis sebagai salah satu sumbert pembiayaan usaha. Peran strategis bank berkaitan dengan fungsi intermediasi bank. Fungsi intermediasi bank yaitu membantu pihak yang kele-bihan dana dengan pihak yang kekurangan dana. Kepercayaan merupakan modal yang sangat penting bagi bank. Fungsi intermediasi bank dapat berjalan dengan baik apabila kepercayaan masyarakat terhadap bank sangat tinggi.Dengan memiliki kepercayaan masyarakat yang tinggi, ma-ka bank dapat meningkatkan profitabilitasnya. Hal ini berarti bahwa bank akan berkembang menjadi lebih besar lagi dengan memiliki total asset yang besar. Untuk menjaga kepercayaan masyarakat tersebut, maka bank harus sehat atau tidak dalam kondisi financial distress.

Financial distress merupakan suatu kondisi dimana suatu perusahaan mengalami kesulitan keuangan. Perusahaan yang mengalami Financial distress dapat mengarah pada kebangkrutan (Almilia dan Kristijadi, 2003). Perusahaan yang mengalami financial distress tidak selalu mengarah pada kebangkrutan. Jika financial distress terjadi pada bank, maka akan berdampak pada kepercayaan masyarakat. Kondisi ini tidak hanya berefek pada bank yang bersangkutan saja, tetapi juga dapat merembet pada bank-bank yang lain. Kondisi ini dikenal dengan efek domino. Bank akan sangat berhati-hati dalam pengelolaan dananya agar tidak mengalami financial distress. Risiko bank bisa berdampak sistematik, yaitu bisa menyebabkan bank-bank sehat masuk ke dalam pusaran arus yang berbahaya serta menyebabakan krisis kepercayaan masyarakat. Model financial distress atau kondisi bermasalah pada bank perlu untuk diketahui, baik oleh mana-jemen maupun stakeholder. Informasi dini tentang kondisi bank yang cenderung mengalami financial distress akan bermanfaat bagi manajemen, maupun stakeholder. Sehingga dapat dilakukan penanganan secara le-bih cepat. Dengan mengetahui kondisi bermasalah perusahaan sejak dini diharapkan dapat dilakuan tindakan antisipatif agar tidak terjadi kondisi kebangkrutan (Almilia \& Kristijadi, 2003; Almalia dan Herdiningtyas, 2005). Model finan-cial distress merupakan alat untuk mengidentifikasi sebelum dan pada saat krisis keuangan (Almilia, 2006).

Untuk memprediksi adanya kondisi bermasalah yang dialami oleh suatu perbankan, pihak-pihak eksternal tersebut biasanya bereaksi terhadap sinyal distress, seperti tagihan dari bank, masa-lah kualitas produk. Perusahaan yang tidak mam-pu membayar hutang merupakan sinyal awal perusahaan mengalami financial distress. Dengan diketahuinya sinyal distress, perbankan diharapkan dapat melakukan tindakan untuk memperbaiki kondisi perbankan.

Good corporate governance (GCG) merupakan sistem yang mengatur dan mengendalikan perbankan untuk menciptakan nilai tambah (value added) untuk para pemegang saham atau shareholder. Dalam konsep good corporate governance terdapat prinsip-prinsip yang diperlukan, yaitu transparancy, accountability, dan responbility, independency, dan fairness. Komponen-komponen tersebut penting dalam implemenetasi good corporate governance karena terbukti dapat meningkatkan kualitas kinerja bank. Perusahaan-perusahaan besar yang telah mengimplementasi GCG menunjukkan perbaikan kinerja perusahaan dan valuenya meningkat (Seog, 2007). Manajer yang mengutamakan kepentingannya sendiri dapat ditekan dengan impelemnatasi GCG (Yun , 2006).

GCG telah menjadi fokus stakeholder dalam pengelolaan bisnis. Li, Wang dan Deng (2008) implementasi GCG yang rendah telah menjadi salah satu faktor terjadinya krisis keuangan di Negaranegara Asia tahun 1997-1998, sehingga kepercayaan investor menurun. Implementasi GCG yang rendah berakibat kinerja perusahaan yang mengalami penurunan, sehingga kondisi keuangan memburuk dan financial distress.

Risiko kredit merupakan risiko yang timbul karena debitur tidak mampu mengembalikan kredit sesuai dengan akadnya. Non performance loan (NPL) merupakan indikator untuk mengukur tingkat risiko kredit suatu bank. NPL yang semakin tinggi mengindikasikan manajemen kredit suatu bank kurang baik. Manajemen kredit akan terkait dengan mulai bagaimana proses penyaluran kredit, pencairan kredit dan pemantauan serta pengawasan kredit. Bank dengan manajemen kredit yang baik akan mampu menopang kinerja bank yang semakin baik. Bank dengan tingkat NPL yang semakin rendah, maka bank tersebut semakin sehat. Bank dengan NPL yang semakin rendah, akan berdampak pada profitabilitas dan kesehatan bank. Haryanto (2016) menemukan bahwa risiko kredit berpengaruh negatif terhadap profitabilitas bank. Sebaliknya, semakin tinggi NPL, maka kecenderungan kesehatan bank akan turun. 
Earnings menunjukkan kemampuan manajemen dalam mengelola perusahaan untuk memperoleh laba. Tingkat profitabilitas yang semakin tinggi menunjukkan pengelolaan perusahaan semakin baik. Bank dengan profitabilitas yang semakin tinggi kecenderungan bank mengalami financial distress akan semakin kecil. Perkembangan suatu bank juga akan terwujud dengan adanya persaingan, semakin tinggi persaingan antar bank, maka akan menyebabkan jumlah biaya yang dikeluarkan perusahaan semakin tinggi. Pada akhirnya berpengaruh pada tingkat profitabilitas perusahaan. Apabila bank mengalami kerugian, akan menyebabkan penurunan ekuitas bank. Penurunan ekuitas akan menyebabkan menurunnya jumlah aset yang dimiliki bank. Kondisi ini akan berdampak pada keuangan perusahaan yang dapat memicu terjadinya financial distress.

Penelitian Lawrence et al. (2015) menemukan bahwa profitabilitas berpengaruh negatif terhadap financial distress. Sedangkan temuan Antikasari dan Djuminah (2017), dan Azwar (2015) menunjukkan bahwa profitabilitas yang diproksikan dengan ROA berpengaruh terhadap financial distress dengan arah positif. Hasil yang berbeda ditemukan dalam penelitian Al-khatib dan Horani (2012) di-mana profitabilitas tidak berpengaruh terhadap fi-nancial distress.

Kepercayaan menjadi faktor penting bagi bank. Bank yang mengalami financial distress akan berdampak pada kesehatan bank. Bank yang tidak sehat akan dapat berimplikasi pada kepercayaan masyarakat terhadap bank yang bersangkutan. Penurunan kepercayaan pada suatu bank akan dapat berdampak pada kepercayaan masyarakat untuk menyimpan dananya di bank tersebut. Hal ini tentunya akan berdampak pada kemampuan bank dalam menghimpun dana pihak ketiga. Sehingga kemampuan bank untuk menyalurkan kredit juga akan menurun, yang selanjutnya berimbas pada penurunan pendapatan.

Ukuran bank menggambarkan seberapa besar total aset yang dimiliki suatu bank. Total aset menunjukkan kemampuan dalam mendanai investasi yang menguntungkan dan kemampuan untuk memperluas pasar serta mempunyai prospek yang baik. Hal ini juga memudahkan bank dalam melakukan fungsi utamanya, yaitu menghimpun dana dan menyalurkan dana. Semakin besar total aset yang dimiliki bank, mengindikasikan bank mampu menghimpun dana. Bank dengan aset yang tinggi, maka bank mempunyai potensi untuk menyalurkan kredit yang semakin besar, sehingga bank berpotensi untuk mendapatkan pendapatan yang besar dengan syarat tetap menerapkan prin-sip kehati-hatian.

Penelitian terkait dengan financial distress telah banyak dilakukan. DeAngelo, DeAngelo dan Wruc (2002) meneliti tentang likuiditas aset dengan financial distress. Utami, Subroto, dan Saputra (2015) terkait dengan financial indicators dalam memprediksi financial distress. Penelitian GCG dengan financial distress dilakukan oleh Ellen dan Juniarti (2013), Fadhilah dan Syafruddin (2013). Penelitian dengan GCG telah banyak dilakukan, namun temuan penelitian menunjukkan hasil yang tidak konsisten. Temuan penelitian Fadhilah dan Syafruddin (2013) menunjukkan bahwa kepemilikan manajerial dan proporsi komisaris independen berpengaruh negatif terhadap financial distress. Temuan penelitian Garay dan Gonzales (2008) menunjukkan kepercayaan investor meningkat pada perusahaan yang mengimplementasikan GCG. Hal ini karena manajer untuk melakukan manipulasi cash flow lebih rendah. Investor akan tertarik untuk menginvestasikan dananya pada perusahaan. Temuan Ellen dan Juniarti (2013) menunjukkan bahwa nilai GCG secara konsisten tidak mampu memprediksi financial distress. Temuan penelitian Permatasari dan Novitasary (2014) menunjukkan bahwa Implementasi GCG tidak berpengaruh terhadap Kinerja Perbankan di Indonesia. Tujuan penelitian ini adalah untuk me-ngetahui pengaruh GCG, risiko kredit, profita-bilitas, permodalan, dan ukuran perusahaan terhadap Financial Distress.

\section{PENGEMBANGAN HIPOTESIS}

Kualitas implementasi GCG yang baik akan menempatkan kepentingan semua pihak yang ter-kait dengan perusahaan. Perusahaan yang mengimplemEntasikan GCG secara baik, kepentingan manajer tidak menjadi fokus. Kepuasan shareholder dan stakeholder menjadi fokus manajer, sehingga kinerja dan value perusahaan akan meningkat. Perusahaan akan dikelola dengan prinsip-prinsip: transparancy, accountability, dan responbility, independency, dan fairness, mulai dari perencanaan, kebijakan dan implementasi kebijakan. GCG akan dapat meningkatkan kinerjanya, sehingga kecenderungan perusahaan mengalami financial distress akan semakin kecil. Penelitian Emirzon (2006), dan Nuswandari (2009) menunjukkan bahwa GCG mampu meningkatkan kinerjanya. Citra perusahaan dan kepuasan pelanggan akan cenderung meningkat seiring dengan pe- 
ningkatan kualitas implementasi GCG. Hipotesis dalam penelitian ini dapat dirumuskan:

$\mathrm{H}_{1}$ : GCG berpengaruh terhadap financial distress.

Secara tradisional pendapatan bank masih didominasi dari bunga kredit. Sehingga manajemen kredit yang baik, akan berdampak positif terhadap pendapatan bank, dan selanjutnya akan berdampak langsung pada kinerja bank. Manajemen kredit akan sangat terkait dengan manajemen risiko yang dilakukan oleh suatu bank. Semakin baik manajemen risiko suatu bank, maka risiko kredit bank akan dapat ditekan. Semakin rendah risiko kredit, maka kecenderungan bank mengalami financial distress akan semakin rendah. Temuan penelitian Kowanda, Pasaribu dan Firdaus (2014), Nugroho (2012) menunjukkan NPL berpengaruh positif terhadap kemungkinan bank mengalami financial distress. Temuan penelitian Permatasari dan Novitasary (2014), Poudel (2012) dan Aebi, et al (2011) menunjukkan bahwa NPL berpengaruh negatif terhadap ROE. Hipotesis dalam penelitian ini dapat dirumuskan:

$\mathrm{H}_{2}$ : Risiko kredit berpengaruh terhadap financial distress.

Kesehatan bank menjadi salah satu fokus penting dalam penilaian kinerja suatu bank. Kinerja bank dapat diukur dari profitabilitasnya, yaitu return on asset (ROA). Semakin tinggi ROA menunjukkan kinerja bank akan semakin baik. Bank dengan profitabilitas yang semakin tinggi, maka bank tersebut akan semakin kecil mengalami financial distress. Bank dengan profitabilitas yang tinggi me-nunjukkan bahwa bank tersebut dikelola dengan baik. Bank dengan kinerja yang buruk, atau mengalami kerugian maka bank tersebut akan dapat mengalami financial distress. Penelitian Rahmania (2014) dan Tarmizi dan Kusuno (2003) menunjukkan bahwa profitabilitas berpengaruh negatif terhadap financial distress. Hipotesis dalam penelitian ini dapat dirumuskan: $\mathrm{H}_{3}$ : Profitabilitas berpengaruh terhadap financial distress.

Permodalan bank menjadi salah satu faktor yang mempengaruhi kesehatan bank. Bank Indonesia telah menentukan besarnya CAR minimal un-tuk kesehatan bank. CAR merupakan ukuran permodalan bank. CAR menunjukkan kecukupan modal suatu bank untuk menunjang aktiva yang me-ngandung risiko. Semakin tinggi tingkat CAR suatu bank, maka kecenderungan bank akan mengalami financial distress akan semakin kecil. Penelitian Almilia dan Herdiningtyas (2005), Abdullah (2008) menunjukkan CAR berpengaruh nega- tif terhadap financial distress. Hipotesis dalam penelitian ini dapat dirumuskan:

$\mathrm{H}_{4}$ : CAR berpengaruh terhadap financial distress.

Dana pihak ketiga (DPK) merupakan sumber pembiayaan yang dominan bagi suatu bank. Sema-kin besar aset suatu bank menunjukkan kemampuan bank menghimpun dana masyarakat akan semakin besar. Bank sebagai lembaga intermediasi, maka DPK merupakan sumber dana potensial bagi untuk menyalurkan kredit. Bank dengan asset yang besar, maka menunjukkan bahwa bank tersebut memilki kemampuan untuk menguasai pasar semakin besar. Penguasaan pasar yang semakin besar, baik itu sisi pendanaan maupun kredit akan cenderung kinerja bank tersebut akan semakin baik. Perusahaan dengan aset yang semakin besar akan cenderung memiliki kinerja yang lebih baik (Lisa, Chandrarin dan Subiyantoro, 2014). Penelitian Kristanti (2014) menunjukkan bahwa ukuran bank berpengaruh negatif terhadap financial distress. Hipotesis dalam penelitian ini dapat dirumuskan:

H5: Ukuran bank berpengaruh terhadap financial distress

\section{DATA DAN METODE}

Penelitian ini merupakan penelitian deskriptif kuantitatif, yang menjelaskan hubungan hu-bungan sebab akibat. Sumber data yang digunakan berupa laporan keuangan bank yang telah diaudit. Populasi dalam penelitian ini merupakan bank devisa yang terdaftar di Bank Indonesia. Jumlah populasi sebanyak 35 bank. Teknik sampling yang digunakan purposive sampling, dengan kriteria: BUSN devisa yang mempublikasikan secara kontunue laporan keuangan tahun 20132016. Jumlah sampel dalam penelitian ini sejumlah 17 bank, dengan periode pengamatan 4 tahun. Jumlah data observasi sebanyak 68 data.

Operasionalisasi variabel yang digunakan dalam penelitian ini disajikan pada Tabel 1. Variabel Penelitian prediksi financial distress pada BUSN devisa dengan vaiabel independen good corporate governance, risiko kredit, profitabilitas, permodalan dan ukuran bank.

Analisis data dilakukan dengan melakukan secara bertahap, yaitu dengan mengempokkan kondisi bank berdasarkan kondisi financial distress, yaitu kondisi financial distress, grey area dan nonfinancial distress. Teknik analisis data yang digunakan regresi linear berganda untuk pada masing-masing kondisi dan secara keseluruhan (Chandrarin, 2017). 
$Y=\beta_{0}+\beta_{1} X_{1}+\beta_{2} X_{2}+\beta_{3} X_{3}+\beta_{4} X_{4}+\beta_{5} X_{5}+e$

Di mana Y: Financial distress; $\beta_{0}$ : Konstansta; $\beta_{1-5}$ : Koefisien regresi; $\mathrm{X}_{1}$ : Good Coprporate Governance;
$\mathrm{X}_{2}$ : Risiko Kredit (NPL); $\mathrm{X}_{3}$ : Profitabilitas; (ROA); $\mathrm{X}_{4}$ : Permodalan bank (CAR); $\mathrm{X}_{5}$ : Ukuran bank dan e: Error

Tabel 1 Definisi Operasional

\begin{tabular}{|c|c|c|}
\hline Variabel & Definisi Operasional & Ukuran \\
\hline $\begin{array}{l}\text { Financial } \\
\text { Distress }\end{array}$ & $\begin{array}{l}\text { Bank yang mengalami kegagalan dalam menja- } \\
\text { lankan operasi bank untuk menghasilkan laba }\end{array}$ & $\begin{array}{l}\text { Z-Score }=6,56 \mathrm{X} 1+3,2 \mathrm{X} 2+6,72 \mathrm{X} 3+ \\
1,05 \mathrm{X} 4\end{array}$ \\
\hline $\begin{array}{ll}\text { Good } & \text { Corpo- } \\
\text { rate } & \text { Gover- } \\
\text { nance } & \end{array}$ & $\begin{array}{l}\text { Variabel ini diukur dengan Proporsi Komisaris } \\
\text { Independen, yaitu perbandingan jumlah anggota } \\
\text { komisaris independen dengan total seluruh ang- } \\
\text { gota komisaris }\end{array}$ & $\begin{array}{l}\text { Proporsi Komisaris Independen = } \\
\frac{\text { Jumlah Komisaris Independen }}{\text { Total Seluruh Anggota Komisaris }} \times 100 \%\end{array}$ \\
\hline $\begin{array}{l}\text { NPL (Non } \\
\text { Performing } \\
\text { Loan) }\end{array}$ & $\begin{array}{l}\text { Nisbah antara jumlah kredit bermasalah dengan } \\
\text { jumlah total kredit yang diberikan bank. }\end{array}$ & NPL $=\frac{\text { Kredit Bermasalah }}{\text { Total } \text { Kredit }} \times 100 \%$ \\
\hline Profitabilitas & $\begin{array}{l}\text { ROA (Return On Asset), yaitu Kemampuan bank } \\
\text { untuk memperoleh laba dari aktiva bank. }\end{array}$ & ROA $=\frac{\text { Laba Sebelum pajak }}{\text { Total Ahtiva }} \times 100 \%$ \\
\hline $\begin{array}{l}\text { CAR (Capital } \\
\text { Adequecy } \\
\text { Ratio) }\end{array}$ & $\begin{array}{l}\text { CAR merupakan perbandingan antara modal } \\
\text { dengan aktiva terimbang menurut risko (ATMR) }\end{array}$ & $\begin{array}{l}\text { CAR }=\frac{\text { Modal Bank }}{\text { Ahtiva Tertimbang menurut Risiko }} \\
x 100 \%\end{array}$ \\
\hline $\begin{array}{l}\text { Ukuran } \\
\text { Bank }\end{array}$ & Ukuran bank dilihat dari total asset suatu bank. & Ukuran bank $=\operatorname{Ln}$ (Total Asset) \\
\hline
\end{tabular}

\section{HASIL}

\section{Deskripsi Data}

Deskripsi data yang digunakan dalam penelitian ini meliputi variabel dependen yaitu Financial Distress yang diukur dengan Altman Z-Score. Variabel independen yaitu Risk yang diukur dengan Risiko bank yang diproksikan dengan Net Performing Loan (NPL), Good Corporate Governance yang diukur dengan Proporsi Komisaris Independen, profitabilitas yang diproksikan dengan Return On Asset (ROA), Capital yang diukur dengan Capital Adequacy Ratio (CAR), dan ukuran bank yang diukur dengan Ln(Total Aset). Penelitian ini menggunakan data tahun 2013-2016 pada Bank Umum Swasta Nasional Devisa. Hasil deskripsi data model Altman Z-Score ditunjukkan pada tabel 2.

Berdasarkan Tabel 2 hasil rata-rata Z-Score periode 2013-2016 terdapat 3 bank yang masuk kondisi financial distress, 12 bank yang masuk kondisi grey area, dan 2 bank yang masuk kondisi non financial distress. Hal ini menunujukkan bahwa sebagian besar $(70,59 \%)$ bank dalam kondisi grey area.

Berdasarkan Tabel 3 dijelaskan bahwa rata- rata risiko bank sebesar 2,91\%. Hal ini menunjukkan kredit bermasalah pada bank rendah. Ketentuan Bank Indonesia NPL $<5 \%$. Hal ini menunjukkan kemampuan bank dalam mengelola kredit dinilai baik dan dikatakan sehat. Rata-rata Proporsi Komisaris Independen sebesar 0,59\%. Hal ini menunjukkan pengawasan yang dilakukan oleh komisaris independen sangat rendah. Rata-rata ROA sebesar $1,06 \%$. Hal ini menunjukkan tingkat laba yang dihasilkan bank cukup baik, bahkan beberapa bank ROAnya diatas 1,5\%. ROA tertinggi sebesar $3,88 \%$ sehingga bank dikategorikan sangat sehat. Rata-rata CAR sebesar 19,06\%. CAR bank rata-rata sudah memenuhi ketentuan BankIndonesia. Hal ini menunjukkan tingkat kemampuan bank dalam mencukupi modalnya sangat baik $(>12 \%)$, sehingga kemampuan bank dikategorikan sangat sehat. Rata-rata ukuran bank sebesar 90.552 .823 juta. Hal ini menunjukkan bahwa total aset yang dimiliki bank dinilai cukup besar.

Pada Tabel 4 dijelaskan mengenai pengaruh dari masing-masing variabel independen terhadap variabel dependen untuk 4 kondisi. Berdasarkan hasil analisis menunjukkan bahwa dalam kondisi financial distress, grey area, non financial distress dan 
semua bank menunjukkan bahwa Good Corporate Governance dan risiko bank tidak berpengaruh terhadap financial distress. Hal ini berarti hipotesis 1 dan hipotesis 2 ditolak. Sedangkan profitabilitas,
CAR dan ukuran bankberpengaruh terhadap financial distress. Hal ini berarti hipotesis 3, 4 dan hipotesis 5 diterima.

Tabel 2. Hasil Deskripsi Model Altman Z-Score

\begin{tabular}{|c|c|c|c|c|c|c|}
\hline \multirow{2}{*}{$\begin{array}{l}\text { Nama } \\
\text { Bank }\end{array}$} & \multicolumn{4}{|c|}{$Z=6,56 X 1+3,2 X 2+6,72 X 3+1,05 X 4$} & \multirow{2}{*}{$\begin{array}{l}\text { Rata- } \\
\text { rata }\end{array}$} & \multirow{2}{*}{ Keterangan } \\
\hline & 2016 & 2015 & 2014 & 2013 & & \\
\hline AGRO & 1,8632 & 1,2916 & 1,9685 & 1,3660 & 1,6223 & Grey Area \\
\hline BBKP & 0,9366 & 1,1559 & 1,0815 & 1,2319 & 1,1015 & Grey Area \\
\hline BNBA & 1,5732 & 1,2575 & 1,0546 & 1,2832 & 1,2921 & Grey Area \\
\hline BABP & 0,9965 & 0,9116 & 0,8787 & 0,5003 & 0,8218 & Financial Distress \\
\hline BBCA & 2,5177 & 2,4253 & 2,3536 & 2,0717 & 2,3421 & Grey Area \\
\hline BNGA & 1,5448 & 1,5053 & 2,1416 & 1,7725 & 1,7411 & Grey Area \\
\hline BDMN & 3,0744 & 2,9490 & 3,0327 & 3,0912 & 3,0368 & Non Financial Distress \\
\hline SDRA & 2,0308 & 1,8173 & 1,9427 & 1,5253 & 1,8290 & Grey Area \\
\hline $\mathrm{BNII}$ & 1,6431 & 1,6486 & 1,8339 & 1,6413 & 1,6917 & Grey Area \\
\hline BKSW & 0,5856 & 1,0748 & 0,9829 & 1,3545 & 0,9995 & Financial Distress \\
\hline BMAS & 1,6428 & 1,1646 & 1,0926 & 1,3594 & 1,3148 & Grey Area \\
\hline MEGA & 1,6802 & 1,5482 & 1,2444 & 1,0063 & 1,3698 & Grey Area \\
\hline BBMD & 2,8573 & 3,1184 & 3,2869 & 3,4270 & 3,1724 & Non Financial Distress \\
\hline $\mathrm{BCIC}$ & $-1,6960$ & $-2,0910$ & $-2,0659$ & $-2,0295$ & $-1,9706$ & Financial Distress \\
\hline NISP & 1,8547 & 2,0664 & 2,3552 & 2,1714 & 2,1119 & Grey Area \\
\hline BSIM & 1,3897 & 1,0591 & 1,2262 & 1,2697 & 1,2362 & Grey Area \\
\hline BSWD & 0,7133 & 1,7905 & 2,0133 & 1,5859 & 1,5258 & Grey Area \\
\hline
\end{tabular}

Sumber: Data diolah

Tabel 3. Deskripsi Data

\begin{tabular}{lrrr}
\hline Variabel & \multicolumn{1}{c}{ Rata-rata } & Maximum & \multicolumn{1}{c}{ Minimum } \\
\hline NPL $($ X1) & $2,91 \%$ & $8,7975 \%$ & $0,685 \%$ \\
KI $($ X2) & $0,59 \%$ & $0,75 \%$ & $0,5 \%$ \\
ROA $($ X3) & $1,06 \%$ & $3,88 \%$ & $-5,74 \%$ \\
CAR $(X 4)$ & $19,06 \%$ & $29,18 \%$ & $14,47 \%$ \\
SIZE $($ X5) & $90.552,8 \mathrm{~m}$ & $580.279,25 \mathrm{~m}$ & $4.798,88 \mathrm{~m}$ \\
\hline
\end{tabular}

Sumber: data diolah

Tabel 4. Hasil Pengujian Variabel

\begin{tabular}{lllll}
\hline \multicolumn{1}{c}{ Variabel } & \multicolumn{3}{c}{ Koefisien } \\
& K1 & K2 & K3 & \multicolumn{1}{c}{ K4 } \\
\hline Constanta & $-5,697$ & $-6,816$ & $-2,597$ & 2,868 \\
Non Performing Loan (X1) & 0,02 & 0,092 & 0,017 & $-0,027$ \\
Proporsi Komisaris Independen (X2) & $-0,866$ & 0,911 & 0,182 & 0,429 \\
Return On Assets (X3) & $-0,288^{*}$ & $-0,441^{*}$ & $-0,113$ & $-0,137^{*}$ \\
Capital Adequacy Ratio (X4) & $-0,092^{*}$ & $-0,211^{*}$ & $-0,014$ & $-0,013$ \\
Size (X5) & $-0,179^{*}$ & $-0,107$ & $-0,117^{*}$ & - \\
\hline
\end{tabular}

Sumber: Olahan data

Catatan: * Signifikan pada $\alpha$ : 0,05. K1: Untuk Semua Kondisi; K2: Untuk Kondisi Financial Distress; 


\section{K3: Untuk Kondisi Grey Area; K4: Untuk Kondisi Non Financial Distress}

\section{PEMBAHASAN}

\section{Pengaruh GCG Terhadap Financial Distress}

GCG dalam penelitian ini diukur dengan proporsi komisaris independen mampu memprediksi terhadap financial distress untuk semua kondisi, financial distress, grey area, dan non financial distress. Proporsi komisaris independen sangat rendah. Jumlah komisaris independen yang rendah, maka akan berdampak pada kurangnya efektifitas pengawasan yang dilakukan terhadap manajemen. Tidak berpengaruhnya GCG terhadap financial distress dapat disebabkan oleh kurang seriusnya implementasi GCG yang dilakukan oleh suatu perusahaan. GCG hanya sekedar formalitas belaka. Hal ini sesuai dengan temuan penelitian Carningsih (2009), dimana ke-beradaan komisaris independen di suatu perusahaan sering kali hanya sekedar memenuhi ketentuan yang berlaku saja. Kondisi ini berakibat fungsi pengawasan yang seharusnya dapat dilakukan oleh komisaris independen menjadi tidak berjalan sebagaimana yang diharapkan. Perusahaan telah mempraktikan GCG, namun implementasi GCG belum sepenuhnya dilakukan (Amanti, 2011). Kondisi ini yang cenderung mem-buat CGC tidak mampu memprediksi financial distress. Hasil penelitian ini tidak mendukung temuan penelitiaan Emirzon (2006), dan Nuswandari (2009).

\section{Pengaruh Risko kredit Terhadap Financial Dis- tress}

Hasil penelitian menunjukkan bahwa risiko kredit tidak berpengaruh terhadap financial distress. Bank dengan kondisi kredit bermasalah yang rendah, kemungkinan kecil akan mengalami financial distress. Hal ini terjadi karena risiko kredit yang diukur dengan NPL bank-bank devisa di Indonesia cukup rendah hanya 2,91 \% (Tabel 3). Kredit bermasalah bank-bank devisa masih di bawah ketentuan Bank Indonesia, yang mematok ketentuan kredit bermasalahnya kurang dari 5\%. Bank dengan kredit bermasalah yang rendah, menunjukkan bank-bank umum nasional devisa dalam kondisi yang sehat. Bank dengan kredit bermasalah yang rendah, maka kolektibilitas kredit baik atau lancar sehingga tidak sampai berpengaruh pada financial distress. Risiko kredit bank-bank di Indonesia yang rendah tersebut tidak dapat digunakan untuk memprediksi financial distress. Hasil penelitian ini tidak mendukung penelitian Rahmania (2014), Kowanda, Pasaribu dan Firdaus (2014), dan Nu-groho (2012).

\section{Pengaruh Profitabilitas Terhadap Financial Dis- tress}

Berdasarkan hasil penelitian menunjukkan profitabilitas (ROA) berpengaruh signifikan terha-dap financial distress dengan arah negatif. Profitabilitas berpengaruh terhadap financial distress, baik pada kondisi perusahaan mengalami financial distress, maupun pada bank-bank yang tidak mengalami financial distress. Sedangkan profitabilitas tidak berpengaruh terhadap financial distress pada bank-bank dalam kondisi grey area. Hal ini menunjukkan bahwa semakin tinggi kemampuan bank membukukan laba, maka kecenderungan untuk mengalami financial distress akan semakin kecil. Semakin besar laba yang mampu dibukukan bank, maka bank akan memiliki kemampuan untuk menyisihkan laba sebagai laba ditahan. Semakin besar laba ditahan suatu bank, maka tambahan ekuitas bank akan semakin besar. Bank dengan tambahan ekuitas yang meningkat akan memiliki kesempatan untuk melakukan investasi usahanya.

Sumber dana dari peningkatan ekuitas memiliki keuntungan bagi bank, karena biaya dananya rendah atau bahkan tidak ada. Bank dapat menggunakan tambahan dana dari ekuitas untuk investasi jangka panjang, seperi untuk pembelian aktiva tetap atau investasi jangka panjang lainnya. Bagi bank sumber dana dari laba ditahan lebih menguntungkan dan lebih leluasa memanfaatkan dibandingkan sumber dana dari DPK.

Bank dengan tingkat profitabilitas yang tinggi menunjukkan penggunaan aset bank yang efektif, sehingga dapat menekan pengeluaran biaya. Bank dapat melakukan penghematan biaya, sehingga bank kecenderungan bank mengalami financial distress semakin kecil. Hasil penelitian ini mendukung temuan penelitian Almilia dan Herdiningtyas (2005) dan Abdullah (2008), Lawrence et al. (2015). Namun tidak mendukung temuan Antikasari dan Djuminah (2017), Azwar (2015) dan Al-khatib dan Horani (2012).

\section{Pengaruh Capital Adequacy Ratio Terhadap Financial Distress}

Berdasarkan Tabel 4 menunjukkan bahwa CAR bank-bank umum swasta nasional devisa berpengaruh terhadap financial distress dengan arah negatif untuk semua kondisi dan kondisi financial distress. Hal ini disebabkan karena sema- 
kin tinggi CAR menunjukkan kemampuan bank dalam memenuhi permodalannya sangat baik, sehingga probabilitas bank dalam kondisi bermasalah semakin kecil. Hasil tersebut menunjukkan bahwa faktor permodalan mempunyai pe-ngaruh terhadap financial distress.

Bank Indonesia selaku otoritas moneter telah menetapkan batas minimum CAR $12 \%$.Penentuan CAR tersebut upaya agar bankdapat melindungi dana deposannya. Semakin tinggi CAR suatu bank, maka tingkat kesehatan bank akan semakin baik, sehingga kecenderungan bank mengalami financial distress akan semakin kecil. Temuan penelitian ini mendukung penelitian Almilia dan Herdiningtyas (2005), namun tidak mendukung penelitian Rahmania (2014).

\section{Pengaruh Ukuran Bank Terhadap Financial Dis- tress}

Hasil penelitian menunjukkan bahwa ukuran bank berpengaruh terhadap financial distress dengan arah negatif pada kondisi grey area dan semua kondisi, sedangkan pada kondisi financial distress dan non financial distress ukuran bank tidak berpengaruh. Bank yang besar akan cenderung memiliki jaringan atau cabang yang lebih banyak dan luas, sehingga akan mampu menguasai pangsa pasar baik, dari sisi penghimpunan dana maupun dari sisi kredit. Bank dengan potensi tersebut, akan lebih mampu memperoleh laba dari opreasionalnya, sehingga akan peluang terjadi financial distress akan semakin kecil.

Bank-bank umum swasta nasional devisa dengan aset yang besar, seperti Bank BCA, Bank Cimb Niaga, Bank Danamon dan bank-bank besar lainnya telah memiliki kantor cabang sampai ke daerah-daerah. Dengan keberadaan kantor cabang yang tersebar dengan ditunjang teknologi bank lebih baik, kinerja bank-bank besar cenderung lebih baik. Temuan penelitian ini mendukung penelitian Kristanti (2014).

\section{SIMPULAN DAN SARAN}

Penelitian ini meneliti tentang prediksi $\mathrm{Fi}$ nancial Distress dengan prediktor good corporate governance, risiko kredit, profitabilitas, capital adequacy ratio dan ukuran bank. Penelitian dilakukan dengan melakukan klasifikasi kondisi bank, yaiut bank yang mengalami financial distress, kondisi grey area dan non financial distress. Hasil penelitian menunjukkan bahwa Analisis good corporate governance dan risiko kredit tidak berpengaruh terhadap financial distress pada semua kondisi bank. Profitabilitas, capital adequacy ratio dan ukuran bank berpengaruh terhadap financial distress. Profitabilitas dan capital adequacy ratio berpengaruh terhadap financial distress dengan arah negatif pada kondisi bank yang mengalami financial distress, bank dalam kondisi non financial distress, dan pada gabungan semua bank. Sedangkan ukuran bank berpengaruh terhadap financial distress dengan arah negatif pada kondisi grey area dan pada gabungan semua bank.

Penelitian ini memiliki keterbatasan yaitu bank yang digunakan hanya BUSN devisa serta variabel hanya menggunakan lima variabel saja, yaitu GCG, risiko kredit, profitabilitas, CAR, dan ukuran bank. Variabel GCG hanya digunakan proksi proporsi komisaris independen. Untuk penelitian selanjutnya dapat dilakukan dengan melakukan pembedaan dengan melakukan klasifikasi ukuran bank, proksi variabel GCG dapat digunakan dengan proksi lainya yang lebih komprehensif.

\section{DAFTAR PUSTAKA}

Abdullah, N. A., (2008). Predicting Corporate Failure of Malaysia's Listed Companies: Comparing Multiple Discriminant Analysis, Logistic Regression and the Hazard Model.International Research Journal of Finance and Economics.

Aebi, V., Gabriele S. dan Markus S., (2011). Risk Management, Corporate Governance, and Bank Performance in the Financial Crisis. Journal of Banking and Finance.

Al-khatib, H.B. \& Horani, A.A., (2012). Predicting Financial Distress of Public Companies Listed in Amman Stock Exchange. European Scientific Journal, Vol. 8(15):1-17.

Almilia, L. S. \& Kristidjadi, K., (2003). Analisis Rasio Keuangan Untuk Memprediksi Kondisi Financial Distress Perusahaam Manufaktur Yang Terdaftar di Bursa Efek Jakarta.Jurnal Akuntansi \& Auditing Indonesia, Vol. 7(2).

Almilia, L. S. dan Winny H., (2005). Ananlisis Rasio CAMEL Terhadap Prediksi Kondisi Bermasalah Pada Lembaga Perbankan Periode 2000-2002.Jurnal Akuntansi dan Keuangan, Vol. 7 (2).

Almilia, LS. (2006)., Prediksi Kondisi Financial Distress Perusahaan Go Public Dengan Menggunakan Analisis Multinomial Logit. Jurnal Ekonomi dan Bisnis. Vol. 12 (1): 1-26. 
Antikasari, T. W. dan Djuminah. (2017). Memprediksi Financial Distress Dengan Binary Logit Regression Perusahaan Telekomunikasi. Jurnal Keuangan dan Perbankan, Vol. 21(2): 265-275.

Azwar. (2015). Model Prediksi Financial Distress dengan Binary Logit. Badan Pelatihan dan Pendidikan Keuangan, Vol. 8(1): 1-23.

Chandrain, G., (2017). Metode Riset Akmuntansi.: Pendekatan Kuantitatif. Jakarta: Salemba Empat.

DeAngeloa, H. DeAngelo, L.and W.H. Karen. (2002). Asset liquidity, debt covenants, and managerial discretion in financial distress: the collapse of L.A. Gear. Journal of Financial Economics, 64: 3-34

Ellen dan Juniarti. (2013). Penerapan Good Corparate Governance, Dampaknya Terhadap Prediksi Financial Pada Sektor Aneka Industri dan Barang Konsumsi. Business Accounting Review, Vol. 1(2): 1-13.

Emirzon, J., (2006). Regulatory Driven Dalam Implementasi Prinsip-Prinsip Good Corporate Governance Pada Perusahaan di Indonesia. Jurnal Manajemen $\mathcal{E}$ Bisnis Sriwijaya, Vol. 4(8): 93 - 114.

Fadhilah, N. F. dan Syafruddin, M., (2013). Analisis Pengaruh Katrakteristik Corporate Governance Terhadap Kemungkinan Financial Distress. Diponegoro Journal of Accounting, Vol. 2(2).

Garay, U. dan Gonzales. M. (2008). Corporate Governance and Firm Value : The Case of Venezuela. Journal Compilation Blackwell Publishing Ltd, Vol 16(3).

Haryanto, S., (2016). Profitability Identification of National Banking Through Credit, Capital, Capital Structure, Efisiensi, and Risk Level. Jurnal Dinamika Manajemen, Vol. 7 (1)

Kowanda, D., Pasaribu, B.F R. Firdaus, M., (2014). Financial Distress Prediction on Public Listed Banks in Indonesia Stock Exchange. The $3^{\text {rd }}$ International Congress on Interdisciplinary Behavior \& Social Science. Bali 01-02 Nopember.

Kristanti, F. T., (2014). Prediksi Kebangkrutan Bank-Bank Yang Terdaftar Di Bursa Efek Indonesia. Jurnal Keuangan dan Perbankan. Vol. 18(1): 130-138.
Lawrence J.R., Pongsatat, S. \& Lawrence, H., (2015). The Use of Ohlson's O-Score for Bankruptcy Prediction in Thailand. The Journal of Applied Business Research, 31(6): 2069-2078.

Li-H.X. Wang, Z dan Deng, X., (2008). Ownership, independent directors, agency costs, and financial distress: evidence from Chinese listed company. Corporate Governance Journal. Vol. 8(5): 622-636.

Lisa, O. Chandrarin, G. and Subiyantoro, E., (2014). Firm Characteristic, Demand for External Auditing Services and Financial Perfomance: An Empirical Study on Cooperative Enterprises in East Java, Indonesia. Asia-Pacific Management Accounting Journal, Vol. 9(2).

Nugroho, V., (2012). Pengaruh CAMEL Dalam Memprediksi Kebangkrutan Bank. Jurnal Akuntansi, Vol. 16(1): 145-161.

Nuswandari, C., (2009). Pengaruh Corporate Governance Perception Index Terhadap Kinerja Perusahaan Pada Perusahaan yang Terdaftar di Bursa Efek Jakarta. Jurnal Bisnis dan Ekonomi (JBE), September: 70-84.

Permatasari, I. dan Novitasary, R., (2014). Pengaruh Implementasi Good Corporate Governance terhadap Permodalan dan Kinerja Perbankan di Indonesia: Manajemen Risiko Sebagai Variabel Intervening. Jurnal Ekonomi Kuantitatif Terapan, Vol. 7(1).

Poudel, R. P. S., (2012). The Impact of Credit Risk Management on Financial Performance of Commercial Banks in Nepal. International Journal of Arts and Commerce. Vol. 1(5).

Rahmania, F. M., (2014) Analisis Rasio Keuangan Terhadap Financial Distress Perusahaan Perbankan Studi Empiris Di BEI 2010-2012. Jurnal Ilmu \& Riset Akuntansi, Vol. 3(11).

Seog, S. H., (2007). A Blessing in Disguise : Corporate Governance, Firm Value, and Competition. School of Finance. Seoul.

Tarmizi, A dan Kusuno. (2003). Analisis RasioRasio Keuangan Sebagai Indikator Dalam Memprediksi Potensi Kondisi Bermasalah Perbankan Di Indonesia. Media Ekonomi $\mathcal{E}$ Bisnis. Vol. 15(1).

Utami, Y., Subroto, S., dan Saputra, Y.J.H., (2015). Pengaruh Financial Indicators Dalam 
Memprediksi Financial Distress Perusahaan Manufaktur Di Indonesia Dengan Model Altman Z-Score dan Multinominal Logistic. Prosiding SNaPP2015 Sosial, Ekonomi, dan Humaniora, Vol. 5(1)
Yun, H., (2006). The Choice of Corporate Liquidity and Corporate Governance. Unpublished Thesis, University of Notre Dame. Notre Dame 